\title{
Effect of Human Resource Planning on Organizational Performance of the Hospitality Sector in Nigeria
}

\author{
Friday Ogbu Edeh ${ }^{1^{*}}$ \& Ikechukwu Dialoke ${ }^{2}$ \\ ${ }^{1}$ Department of Business Administration, Alex Ekwueme Federal University, Ndufu-Alike, Ebonyi State, Nigeria \\ ${ }^{2}$ Department of Industrial Relations, Michael Okpara University of Agriculture, Umudike, Nigeria \\ *Corresponding author: edeh.ogbu@gmail.com \\ https://riiopenjournals.com/index.php/business-perspective-review/index
}

Doi: https://doi.org/10.38157/business-perspective-review.v2i1.71

Citation: Edeh, F.O.\& Dialoke, I.(2020). Effect of Human Resource Planning on Organizational Performance of the Hospitality Sector in Nigeria.Business Perspective Review, 2(1), 1-12.Doi: https://doi.org/10.38157/business-perspective-review.v2i1.71

\section{Research Article}

\begin{abstract}
Purpose: The study aims to investigate the effect of human resource planning on the organizational performance of selected hotels in Nigeria.

Method: It is a cross-sectional survey research. A self-developed close-ended questionnaire was used to collect data from managers, supervisors, and front desk officers working in 15 selected hotels operating in Ebonyi state, Nigeria. Descriptive statistics were used to analyze participants' demographic characteristics while regression was used to analyze the hypotheses.

Results: The study found that human resource planning dimensions, namely, adequate funding, competence, age, and cultural background have a positive significant effect on organizational performance.

Implications: The HR managers must focus on the financial capability of the firm as well as the age, competence, and cultural orientation of the prospective employees while making the HR planning.
\end{abstract}

Keywords: Human resource planning, organizational performance, adequate funding, age, cultural background, competence, Nigeria

\section{Introduction}

Performance is one of the paramount objectives of every organization. Williamson (2008) asserts that organizational performance is how well an enterprise is doing in terms of profitability, return on investment, and relationship with the host community as well as its stakeholders. Organizational performance is an indicator of the prosperity and sustainability of the businesses as well as their owners (Robbins, Judge \& Sanghi, 2009; Kinicki \& Kreitner, 2003). Bescos and Cauvin (2004) argued that firms' performance has become a benchmark for successful business rankings especially in service-oriented enterprises. Nevertheless, organizational performance

Published by Research \& Innovation Initiative, 3112 Jarvis Ave, Warren, MI 48091, USA 
cannot be effectively achieved if the organization fails to recruit the right human resource that will carry out organizational objectives. Dessler (2001) argued that the success and failure of firms in the hospitality industry, both in developing and developed countries, largely depends on the competence of their personnel. Mathis and Jackson (2010) also contended that when the right individuals are recruited into the workplace, the goals of the organization are usually achieved without much supervision. Helavalada and Julius (2017) added that human resource planning is the bedrock for every successful organization. Armstrong (2006) also asserted that since the organizational goals depend on the efficiency of the employees, their attraction to the workplace should be taken seriously. Commenting on the efficacy of Human resource management, Biswajeet (2010) argued that when human resource planning fails, every other human resource management practices are bound to fail. On the other hand, Shikha and Karishma (2012) posited that the major causes for underperformance in most service organizations are human resource manager's inability to identify the right employees who will occupy a particular job position within the organization. Their competence, age, education as well as beliefs must conform and be synchronized with the organization's vision and mission.

In planning for human resources, organizations should pay attention to different issues and criteria depending upon the nature of the industry in which they operate. Dialoke (2016) argued that the financial capability of the organization, job requirements and demand, and supply of manpower in a particular profession, etc are important criteria to be considered by the HR managers fro HR Planning. While focusing on the nature of the Hospitality industry, Bhattacharyya (2006) elucidates that age, competence, cultural background, and the financial capability of the organization are the most important criteria for HR planning. Age is very crucial to the performance of any organization especially in the hotel industry. Another imperative element is competence which includes skills needed for the job, and knowledge, and ability to handle a certain task. In addition, for a worthwhile HR planning, the managers must take the financial capability of the organization into consideration as it must sustain the financial demand required to maintain and motivate the workforce.

Another very important concern, especially for the hotel industry, is the cultural orientation of the employees. For instance, some people may not like to work in hotels or lounges because it contradicts with their belief system. For example, serving alcohol or entertaining the guests for their extramarital relationships, etc.

Nonetheless, one of the problems facing most Nigerian service enterprises especially the hospitality industry is inadequate human resource planning. Most of the hotel owners prefer employing their relatives as managers, supervisors, front desk officers, and housekeepers who know nothing about the business (Edeh and Dialoke, 2016). Their perception is that it is all about receiving guests. But they never realize that there is more to hotel management than what they think it is. Some owners even employ their relatives to oversee the affairs of their establishment that ultimately result in the closure of the entire organization. The ineffectiveness recorded in the service deliveries of most hotels is attributed to the qualities of human resources (Eketu and Edeh, 2015). 
Apart from the above problems, some hotel operators do not have adequate funding that may carter to the financial requirements related to employee salaries and other operating costs for the period before the realization of the profit (Edeh and Dialoke, 2016). Similarly, the issue of cultural orientation is also very important in catering to the services related to the hotel industry.

Keeping the above maladies in mind the present study attempts to ascertain the effect of human resource planning on organizational performance of selected hotels in Nigeria.

\section{Literature Review and Hypotheses Development}

\subsection{Human Resource Planning (HRP)}

Human resource planning (HRP) has been a major issue amongst scholars and practitioners in the field of human resource management quite apart from managers in other fields of studies. Human resource planning includes all activities that human resource managers adopt to forecast current and future workforce needs (Management Study Guide, 2017; Jones and George, 2006). Digressing from Jones and George's view, French (1986) argued that human resource planning is a process of anticipating as well as preparing for retiring workers exit and replace them with newcomers. In the same vein, Amah (2006) contended that human resource planning refers to how human resource managers assess the current position of an organization's workforce with reference to what it tends to achieve in the future. Nwachukwu (1998) argued that human resource planning is the process through which management tries to provide information about the number of workers it has and the expected workforce it will require in the future. For Bouldrean and Malkovich (1991), HRP is a process of gathering and using relevant information to support decisions human resource management on how to invest resources in manpower activities. Finally, Bulla and Scott (1994) submitted that human resource planning is the process for ensuring that the manpower requirements of an organization are identified and plans are made for satisfying those requirements. Vetter (1967) viewed human resource planning as the process by which the management determines how the organization should move from its present manpower position to its desired position.

\subsection{Human Resource Planning (HRP) Process}

Several authors have outlined the processes involved in human resource planning based on the situation and industry. Cole (2004) outlined four major processes of human resource planning. It includes, i) analyze the existing human resource situation; ii) forecast future demands for people; iii) assess the external labor market and forecast the supply situation, and iv) establish and implement human resource plans. As argued earlier, the human resource planning process varies from industry to industry based on the processes, operations, geographical location, and such other factors. Human resource planners use forecasting to predict the supply and demand for human resources needed in different sections of the organization. 


\subsection{Determinants of Human Resource Planning}

Validated dimensions of human resource planning include forecasting manpower demand and strategic action (Anya, Umoh and Worlu, 2017); adequate funding, individual competence, age of prospective applicants, cultural background of the applicants (Eketu and Edeh, 2017); compare supply against predicted demand and future manpower (Helavalada and Julius, 2017); recruitment, training and development, employee retention, succession planning (Mbiu and Nzulwa, 2018). Based on the above determinants of human resource planning, this study adopted Eketu and Edeh's (2017) HRP determinants which are adequate funding, individual competence, age, and cultural background. This is because; funding, competence, age, and cultural background of every applicant or human resource are very significant to the survival of every organization.

Adequate funding: When it comes to human resource planning, funding is a major factor that cannot be isolated from the planning process. Finance is a lubricant of the organization; it determines the number of human resources that an organization can accommodate in terms of salary, compensation for either short or long term period. Non-availability of finance can hinder firms from hiring needed skilled human resources that will give them a competitive advantage over their rivals. On the other hand, its availability can boost firms' competitive advantage.

Competence: In this study, competence is concerned with individual abilities, skills, and knowledge related to the job. It is also the ability of the prospective individual who is to be employed to carry out a particular job adequately and effectively. For instance, some individuals may be qualified to carry out a particular job but may not be competent to handle the task required in the job. Also, some can be skillful but may not be adequately competent. Therefore, competence comprises academic qualification, technical skills, conceptual skills, human skills, social intelligence as well as emotional intelligence.

Age: Age is related to different biological and psychological capabilities of the human being. For instance, some jobs may require physical muscular exercise to carry out the job, such as weight lifting, bending, walking, traveling, concentration, etc. Some organizations, military and paramilitary have their age requirement for anyone who wants to join them. Another example can be witnessed in some fast-food restaurants in Nigeria where the age bracket of service attendants is considered to be below 20-25 years (Edeh, Ugwu, Ikpor, Nwali, and Udeze, 2019).

Cultural background: In this study, the cultural background is concerned with the belief system, norms, and values a job applicant possessed before joining a firm. These assumptions can promote or hinder the performance of such individuals especially when the recruiters failed to recognize them at the recruiting point. Thus, during human resource planning, the cultural background of people that will be needed must be considered. For instance, some people will not like to work in the bar section of hotels where all sorts of alcoholic drinks are sold because of his/her belief system. Hence, if such persons are wrongly placed in such a section of the hotel, there is bound to be ineffectiveness on the part of that individual. Based on this premise, human resource practitioners should pay positive attention to the cultures of individuals that want to join any organization to avoid unnecessary turnover and underperformance. 


\subsection{Factors affecting Human Resource Planning}

Dialoke (2016) classified the factors affecting Human Resource Planning factors as internal and external. External factors comprise government policies, changes in the political environment, economic factors such as inflation, deflation, and economic recession. Others are changes in technology, competition amongst firms in the same industry; availability of qualified personnel; changes in an educational environment; demographic characteristics; time frame; lack of planning culture quite apart from market trends. The internal factors consist of adequate finance, organizational structure; organizational size; firm expansion and diversification; changes in operational time; response to business development, and labor turnover.

\subsection{Organizational performance}

Organizational performance is the process of ensuring that firms' resources are properly used in pursuit of their goals (George, 2017). Abdel-Maksoud, Asada, and Nakagawa (2008) defined it as one of the most imperative measures in evaluating organizations' activities and their environment. Bescos and Cauvin (2004) viewed it as an actual output or results of an enterprise as measured against its intended outputs.

Richard, Devinney, Yip, and Johnson (2009) argued that organizational performance focuses on three major areas; shareholder expectation and economic value; financial performance and investment; and production capability. Organizational performance, according to Bibhuti (2008) cited in Salau, Adeniji and Oyewunmi (2014) is the strength and ability of a firm to achieve its goals through employees' retention, wide-range management style, internal work motivation, greater commitment, job satisfaction and career opportunities which have significant and important effects on organizational success. Meyer, Paunonen, Gellatly, Goffin, and Jackson, (1989) added that for a firm's performance to be achieved, such an enterprise must pay attention to how the job of its employees can be enriched quite apart from flexible so as to create strategic change in achieving its objectives.

Some scholars, such as Salau, Adeniji, and Oyewunmi (2014) argued that organizational performance can be sustained with organizational commitment, customers' satisfaction, employees' retention, capacity development, job satisfaction, and enterprise success. It has been shown that enterprise performance is usually associated with effectiveness and efficiency use of enterprise resources (Robbins, Judge, and Sanghi, 2009). This implies that a business organization must render services at the right time with minimum resources.

\subsection{Effect of human resource planning on organizational performance}

Human resource planning is a determinant of how well an organization will perform at any point in time. This is because; if at the point of recruitment, the people that will carry out organizational objectives are not properly selected based on their age, culture, competency, and availability of funding, it will be very difficult for positive performance to be recorded. Thus, it becomes necessary for human resource managers to attract the right people into the organization to avoid underperformance. The age of an applicant during recruitment and selection is very important to the sustenance of production and services. For instance, if the 
organization is such that it's into earth moving equipment, they will require able-bodied men with physical abilities but if the organization is into service delivery, it requires young people. This implies that the age of human resources has a positive or negative effect on organizational performance.

In line with the above, the second indicator of human resource planning is competence. As have been explained in the previous sections, an organization that does not specify job requirement dooms to fail. This is because certain positions require certain competencies such as level of education, training received, and experience, emotional and physical stability as well as affiliated professional bodies. These and many more determine the constituents of competence. If a particular job position requires that the occupant should possess a degree in accounting and the manager went ahead to recruit someone that holds a degree in marketing, the result will be a failure.

However, one other indicator of human resource planning that business practitioners and human resource professionals should not neglect is culture. The culture of an applicant may forbid some business ethics as unethical. Take for instance, recruiting someone who perceived alcohol as abomination into a brewery industry will imply that the organization will be bound to fail because such an employee will never see anything good from the organization as a result of his/her faith. Another example is that an employee maintains religious taboo about a certain type of food that may not perform effectively in a public restaurant where virtually all foods are sold to different customers from diverse cultures. In this case, managers and human resource professionals need to consider culture as one of the determinants of human resource planning in every organization.

The last indicator of human resource planning and the most efficient is funding. Before planning for human resources, human resource managers must take into account the availability of funds that will cater for the salaries of the people that will be recruited over a period of time before profit will be made. This is one of the fundamental factors in human resource planning and without it the organizations cannot make positive headway.

\subsection{Empirical Studies}

Researchers have conducted studies on human resource planning with different dependent variables as well as in different sectors of the economy. Mbiu and Nzulwa (2018) examined the influence of human resource planning on employee productivity in the county government in Kenya. Their findings showed that there is a positive significant correlation between recruitment and deployment, training and development, talent retention, succession planning, and performance of the Council of Governors in Kenya. Anya, Umoh, and Worlu (2017) investigated the relationship between human resource planning and organizational performance in oil and gas firms in Port Harcourt. Their finding revealed that human resource planning has a positive significant relationship with organizational performance and moderated by organizational structure. Mkandatsama and Nyanhete (2017) investigated human resource planning in Zimbabwe's unstable economy using state universities in Zimbabwe as a case study. The finding of their study revealed that human resource planning in Zimbabwe's state 
universities is hindered by a lack of financial resources which is caused by an unstable economy. Talukder and Khan (2013) examined various determinants of human resource planning affecting competitive advantage in a manufacturing firm. Results of their study showed that labor market conditions, goal orientation, performance management, and training were significantly associated with a competitive advantage. Secondly, Maina and Kwasira (2015) examined the role of human resource planning practices on employee performance in Kenya. Their findings revealed that employee attraction and retention moderates employee performance. Farman, et al. (2013) investigated the effect of human resource planning on organizational performance of the telecom sector in the United Kingdom. Their finding shows that human resource planning is positively associated with organizational performance. Eketu and Edeh (2017) examined the relationship between human resource planning and organizational sustainability of selected telecommunication firms in Rivers State using a simple random sampling technique. A sample size of ninety-five was determined using Krejcie and Morgan (1970). Eighty-two copies of the questionnaire were filled properly and returned for data analysis. Spearman's Rank Correlation Coefficient was used for data analysis with the aid of IBM statistical package for social sciences. The result of their study indicated that human resource planning has a significant relationship with organizational sustainability. Rohollah and SeidMehdi (2015) investigated the effect of human resource planning on the quality of services of Melli Bank using a mediating variable of employees' service behaviors from 352 bank employees and 384 customers. The results of their study revealed that there is a significant relationship between human resource planning and the quality of services with service behaviors.

Maryam, Muhammad, and Rab (2014) investigated the impact of enterprise resource planning system implementation on human resource management practices in Pakistan. They selected five organizations which include Nestle Pakistan Ltd, Engro Foods Ltd., Mobilink, LUMS University, and Orient Company Ltd. The sample size of their study is 300 employees. Their finding revealed that enterprise resource planning implementation has a negative relationship with recruitment and selection and did show a relationship with compensation and benefits but has a positive relationship with training and development. Secondly, they also found that recruitment and selection show a negative relation whereas, compensation and benefits and training and development show a positive relationship with organizational productivity.

\subsection{Research Hypotheses}

In line with the extant literature, the following research hypotheses were formulated.

Ho1: There is no significant effect of adequate funding on organizational performance

Ho2: There is no significant effect of employee competence on organizational performance

Ho3: There is no significant effect of employee age and organizational performance

Ho4: There is no significant effect of employee cultural background on organizational performance 


\section{Methodology}

A cross-sectional survey research design was adopted in this study because it supports the use of a questionnaire to collect data from participants within a short period of time (Ahiauzu and Asawo, 2016). The target population comprises of selected hotels operating in Ebonyi state, Nigeria. Specifically, the accessible population in this study consists of fifteen hotels that are registered with the Ebonyi State Ministry of Culture and Tourism.

Convenient sampling was used to select fifteen hotels operating in Ebonyi State and registered with Ebonyi State Ministry of Culture and Tourism. A self-developed close-ended questionnaire was used to collect data from managers, supervisors, and front desk officers. Ninety-two (92) copies of the questionnaire were distributed. However, eighty (80) copies were filled correctly and hence used for analysis. The variables used in the study namely, Adequate funding, competence, age, cultural background, and organizational performance were measured with a 4-item scale for each of the variables on a 5-point Likert scale ranging from strongly agree (5) to Strongly disagree (1).

Descriptive statistics such as frequency distribution and figures were used to analyze participants' demographic characteristics while regression analysis was used to analyze the hypotheses with the aid of the IBM statistical package for social sciences (SPSS 22.0). The validity of the instrument was ascertained using a face validity approach. Cronbach $\alpha$ values for HRP dimensions including, adequate funding (.76); competence (.81); age (.77); cultural background (.69); organizational performance (.73) reveal that all are within the acceptable range.

\section{Results and Discussion}

\subsection{Descriptive Analysis}

Frequency distribution of participants' demographic characteristics revealed that 32 participants representing $40.0 \%$ are females while 48 participants representing $60.0 \%$ are males. Age of the participants also revealed that; 43 participants representing $53.8 \%$ are within $18-30$ years; 20 participants representing $25.0 \%$ fall within $31-40$ years; 17 participants representing $21.3 \%$ are within 41 years and above. On educational qualification, 33 participants representing $41.3 \%$ hold Bachelor degrees; 19 participants representing 23.8\% hold Diploma certificates; 17 participants representing 21.3\% hold Master's degrees; 11 participants representing $13.8 \%$ hold other qualifications which the questionnaire did not capture.

Table 1: Descriptive statistics

\begin{tabular}{|lccccc|}
\hline & N & Minimum & Maximum & Mean & $\begin{array}{c}\text { Std. } \\
\text { Deviation }\end{array}$ \\
\hline Culba & 80 & 1.00 & 5.00 & 1.8750 & 1.29629 \\
\hline Comp & 80 & 1.00 & 5.00 & 1.9125 & 1.44252 \\
\hline Age & 80 & 1.00 & 5.00 & 1.8500 & 1.42403 \\
\hline Adfnd & 80 & 1.00 & 5.00 & 2.3250 & 1.52428 \\
OP & 80 & 1.00 & 5.00 & 2.1875 & 1.36032 \\
\hline Valid N (listwise) & 80 & & & & \\
\hline
\end{tabular}


Table 1 shows that adequate funding (Adfnd) has the highest mean of 2.3250 with a standard deviation of 1.52428 followed by competence (Comp) which has a mean of 1.9125 with a standard deviation 1.44252. This is followed by cultural background (Culba) with mean 1.8750 and standard deviation 1.29629 while age has the lowest mean 1.42403 and standard deviation of 1.42403. On the other hand, organizational performance (OP) has a mean value of 2.1875 and a standard deviation of 1.36032. These have shown that adequate funding is a fundamental element when planning for human resources in the hospitality industry.

\subsection{Test of Hypotheses}

The result in table 2 shows the regression analysis between independent variables (age, cultural background, competence, and adequate funding) and dependent variable (organizational performance). The F-ratio in the ANOVA table shows that the independent variables statistically significantly predict the dependent variable, $\mathrm{F}(4,75)=2.49, \mathrm{p}<0.05, \mathrm{R}^{2}=.667$, and with a high degree of correlation $(\mathrm{R}=.817 \mathrm{a})$. The result also revealed that $\mathrm{p}$-values of independent variables are less than the level of significance (0.05) (age $=.000$; comp $=.000$; culba $=.003$; adfnd =.003). Also, F cal> F tab (37.587 > 2.49). Based on the decision rule, the null hypotheses are hereby rejected and alternate hypotheses accepted. Therefore, the study has found that human resource planning dimensions has a positive significant effect on organizational performance.

\section{Table 2: Regression analysis of human resource planning dimensions and organizational} performance

\begin{tabular}{|c|c|c|c|c|}
\hline \multicolumn{5}{|c|}{ Model Summary } \\
\hline Model & $\mathrm{R}$ & $\begin{array}{c}\mathrm{R} \\
\text { Square }\end{array}$ & $\begin{array}{l}\text { Adjusted R } \\
\text { Square }\end{array}$ & $\begin{array}{l}\text { Std. Error of } \\
\text { the Estimate }\end{array}$ \\
\hline 1 & $.817^{\mathrm{a}}$ & .667 & .649 & .80543 \\
\hline
\end{tabular}

\begin{tabular}{|c|c|c|c|c|c|c|}
\hline \multicolumn{7}{|c|}{ ANOVA $^{a}$} \\
\hline \multicolumn{2}{|c|}{ Model } & $\begin{array}{l}\text { Sum of } \\
\text { Squares }\end{array}$ & df & $\begin{array}{l}\text { Mean } \\
\text { Square }\end{array}$ & F & Sig. \\
\hline \multirow{3}{*}{1} & $\begin{array}{l}\text { Regressio } \\
\mathrm{n}\end{array}$ & 97.533 & 4 & 24.383 & 37.587 & $.000^{\mathrm{b}}$ \\
\hline & Residual & 48.654 & 75 & 649 & & \\
\hline & Total & 146.187 & 79 & & & \\
\hline \multicolumn{7}{|c|}{ a. Dependent Variable: OP } \\
\hline \multicolumn{7}{|c|}{ b. Predictors: (Constant), Adfnd, Comp, Age, Culba } \\
\hline
\end{tabular}


Business Perspective Review, 2(1), 2020

\begin{tabular}{|c|c|c|c|c|c|c|}
\hline \multicolumn{7}{|c|}{ Coefficients $^{a}$} \\
\hline \multirow{2}{*}{\multicolumn{2}{|c|}{ Model }} & \multicolumn{2}{|c|}{$\begin{array}{l}\text { Unstandardized } \\
\text { Coefficients }\end{array}$} & \multirow{2}{*}{$\begin{array}{c}\text { Standardized } \\
\text { Coefficients }\end{array}$} & \multirow[t]{2}{*}{$\mathrm{t}$} & \multirow[t]{2}{*}{ Sig. } \\
\hline & & B & $\begin{array}{l}\text { Std. } \\
\text { Error }\end{array}$ & & & \\
\hline \multirow{5}{*}{1} & (Constant) & .042 & .207 & & .205 & .838 \\
\hline & Culba & .283 & .094 & .270 & 3.020 & .003 \\
\hline & Comp & .330 & .084 & .350 & 3.920 & .000 \\
\hline & Age & .292 & .070 & .305 & 4.172 & .000 \\
\hline & Adfnd & .191 & .061 & .214 & 3.114 & .003 \\
\hline
\end{tabular}

Note: Afnd=Adequate funding; $\operatorname{comp}=$ Competence; age = age of applicants; culba = cultural background of applicants; $\mathrm{OP}=$ Organizational performance.

\section{Conclusion and Implications}

In line with the findings, this study hereby concludes that human resource planning measured in terms of adequate funding, competence, age, and cultural background enhances the organizational performance of hotels in Nigeria. This implies that financial capability is a major element of human resource planning which human resource managers and board of directors must consider before starting a hotel business. It was also discovered that human resource competence is necessary when planning for human resources because if the right individuals are not properly selected during recruitment, it will be very difficult to make a profit that will sustain hotel businesses. Another element that is also found to affect organizational performance is the age of the employees. This study implies that hospitality-based businesses such as hotels require human resources that are smart and resilient to welcome esteemed customers and render quality services. Lastly, the cultural background of human resources is very significant to the survival of any hotel. Hence managers must conduct a proper interview concerning beliefs, values, and norms of all individuals who are willing to work in the industry. This study has contributed to HRM literature especially as HRP is the bedrock for HRM practices such as recruitment, selection, placement, promotion, compensation, and retirement.

\section{Limitations and future research directions}

The study focused on hotels as one aspect of the hospitality sector in Ebonyi state. Thus, the finding of this study cannot be generalized to the whole hospitality industry. Future research should investigate the relationship between HRP and organizational performance of hospitality industries in other states in Nigeria. Future research should examine the effect of HRP on organizational resilience in tourism-based businesses in Nigeria.

Author Contributions: Friday Ogbu Edeh prepared the manuscript, collected data, and analyzed the data. Ikechukwu Dialoke edited the manuscript. 
Conflict of interest: The authors declare no conflict of interest.

\section{REFERENCES}

Abdel-Maksoud, A., Asada, T., \& Nakagawa, M. (2008). Performance measures, managerial practices, and manufacturing technologies in Japanese manufacturing firms: State of the art, International Journal of Business Performance Management, 10(1), 1-16.

Ahiauzu, I.A., \& Asawo, P.S. (2016).Advanced Social Research Methods. Port Harcourt: CIMRAT Publications.

Amah, E. (2006).Human Resource Management. Port Harcourt, Nigeria: Amethyst Publishers.

Anya, C.J.P., Umoh, G.I., \& Worlu, G. (2017).Human resource planning and organizational performance in oil and gas firms in Port Harcourt. International Journal of Advanced Academic Research I Social \& Management Sciences,3(9), 110-129.

Armstrong, M. (2006).Human resources development: The European Approach. Texas: Gulf Publishing Company.

Bescos, P-L., \& Cauvin, E. (2004). Performance measurement in French companies: An empirical study, Studies in Managerial and Financial Accounting,14, 185-202.

Bhattacharyya, D.K. (2006). Human resource planning (2nded.). New Delhi: Excel Books.

Biswajeet, P. (2010). Human Resource Management (3rded.). New Delhi: PHL Learning Private Limited

Bulla, D.N., \& Scott, P.M. (1994).Manpower requirements forecasting: A case example, in Human Resource Forecasting and Modelling, ed D Ward, T.P. Bechet, and R.Tripp, Human Resource Planning Society, New York.

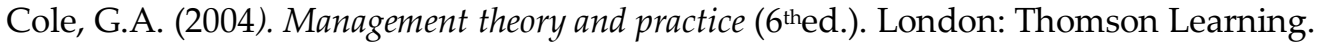

Dessler, G. (2001). Human Resource Management (7thed.). New Delhi: Prentice-Hall.

Dialoke, I. (2016). Advanced human resource planning Ph.D. class note.Department of Industrial Relations \& Personnel Management, Michael Okpara University of Agriculture, Umudike.

Edeh, F.O. \& Dialoke, I. (2016). Talent management strategies and workers' effectiveness. A study of selected hotels in Port Harcourt, Nigeria. International Journal of Knowledge Management and Practices, 5(2), 32-44.

Edeh, F.O., Ugwu, J.N, Ikpor, I.M., Nwali, A.C., \& Udeze, C.C.G. (2019). Organisational culture dimensions and employee performance in Nigerian fast-food restaurants. GIS Business, 14(6), 1070-1096.

Eketu, C.A. \& Edeh, F.O. (2015). Promoting employee loyalty through organisational learning. A study of selected hospitality firms in Port Harcourt, Nigeria. IOSR Journal of Business and Management, 17(11), 39-44.

Eketu, C.A., \& Edeh, F.O. (2017). Human resource planning and organisational sustainability. A study of selected telecommunication firms in Rivers State. International Journal of Social Sciences and Management Research, 3(3),37-46.

Farman, A., Kashif, M., Syed, M.R.S., Muhammad, S., \& Muhammad, H. (2013). Effect of human resource planning on organizational performance of the telecom sector.Information and Knowledge Management, 3(2), 173-182.

Fox, C., \& Miller, H. (1998).Positivism.In J. Shafritz (Ed.) International Encyclopedia of Public Policy and Administration (pp.1718-1723). Boulder, CO: Westview Press.

French, W.L. (1986). Human resource management. Boston, Houghton Mifflin Co. Retrieved from https://en.wikipedia.org/wiki/Strategic_human_resource_planning

George, N.R. (2017). Examples of organizational performance management. Retrieved from http://smallbusiness.chron.com/examples-organizational-performance-management-11508.html.

Helavalada, W., \& Julius, T.N. (2017). Significance of manpower planning for effective utilization of human resources in an organization: A conceptual approach. International Journal of Business and Management Invention, 6(8), 16-2.

Jones, R.G., \& George, M.J. (2006).Contemporary management (4thed.). New York: McGraw-Hill, Irwin.

Kinicki, A., \& Kreitner, R. (2003).Organizational behavior: Key concepts, skills, and best practices. New York: McGrawHill Irwin.

Krejcie, R.V., \& Morgan, D.W. (1970).Determining Sample Size for Research Activities Educational and Psychological Measurement, 30, 607-610.

Management Study Guide (2017).Human resource planning. Retrieved from https://www.managementstudyguide.com/human-resource-planning.htm 
Maina, D.K., \&Kwasira J. (2015). Role of human resource planning practices on employee performance in county governments in Kenya: A case of Nakuru County. International Journal of Economics, Commerce and Management,3(5), 1569-1580.

Maryam, S., Muhammad, S., \& Rab, N.L. (2014). Impact study of enterprise resource planning (ERP) in HRM practices.Middle-East Journal of Scientific Research, 21(1), 218-222.

Mathis, R. L., \& Jackson, J.H. (2010).Human Resource Management (13 thed.). Ohio: South-Western College Publishing.

Meyer, J.P., Paunonen, V., Gellatly, I.R., Goffin, R.D., \& Jackson, D.N. (1989). Organizational commitment and job performance: It's the nature of the commitment that counts. Journal of Applied Psychology, 74(1),152-156.

Mkandatsama, P., \& Nyanhete, T. (2017). Human resource planning in an unstable economy: challenges faced. A case of state universities in Zimbabwe.International Journal of Asian Social Science, 7(3), 206-217.

Noe, A.R., Hollenbeck, R.J., Gerhart, B., \& Wright, M.P. (2004).Fundamentals of human resource management.New York: McGraw Hill, Irwin.

Nwachukwu, C.C. (1998). Personnel Management in Nigeria. Port Harcourt.

Richard, P., Devinney, T., Yip, G., \& Johnson, G. (2009). Measuring organizational performance: Towards methodological best practice. Journal of Management, 35(3) 718-804.

Robins, S.P., Judge, T.A., \& Sanghi, S. (2009). Organizational Behavior (13 thed.). New York: Prentice-Hall.

Rohollah, R., \& SeidMehdi, V. (2015). Investigating the effect of human resource planning (HRP) on the quality of services of Melli Bank via the mediating variable of employees' service behaviors. WALIA Journal, 31(S1), 47-53.

Salau, O., Adeniji, A., \& Oyewunmi, A. (2014). Relationship between elements of job enrichment and organizational performance among the non-academic staff in Nigerian public universities. Management $\mathcal{E}$ Marketing, 3(2), 173-189.

Shikha, N.K., \& Karishma, G. (2012).Human resource planning practices. Journal of Business and Management, 3(6), 06-13.

Talukder, A.K.M.M.H., \& Khan, M.I. (2013). Human resource planning and competitive advantage: Investigating the relationship. KASBIT Business Journal, 6:29-37.

Vetter, E.W. (1967).Manpower planning for high talent personnel, AnuArbur, University of Michigan.

Williamson, M.G. (2008).The effects of expanding employee decision making on contributions to firm value in an informal reward environment. Contemporary Accounting Research, 25(4),1184-209.

(C) 2020 by the authors. Licensee Research $\mathcal{E}$ Innovation Initiative, Michigan, USA. This article is an open-access article distributed under the terms and conditions of the Creative Commons Attribution (CC-BY) license (http://creativecommons.org/licenses/by/4.0/). 